Nevşehir Bilim ve Teknoloji Dergisi Cilt 6(ICAFOF 2017 Özel Sayı) 280-296 2017

DOI: 10.17100/nevbiltek.359408

URL: http://dx.doi.org/10.17100/nevbiltek.359408

\title{
Ordu'da (Türkiye) Yetiştirilen 'Hayward' Kivi Çeşidinin Önemli Kimyasal Bileşenleri ve Fiziksel Özellikleri
}

\author{
Caner Kubal $^{1}$, Bekir Gökçen Mazı², Saim Zeki Bostan ${ }^{1, *}$ \\ ${ }^{1}$ Ordu Üniversitesi, Ziraat Fakültesi, Bahçe Bitkileri Bölümü, Ordu \\ ${ }^{2}$ Ordu Üniversitesi, Ziraat Fakültesi, Gıda Mühendisliği Bölümü, Ordu
}

Öz

Bu araştırma, 2015 yılında Ordu'nun ilçelerinde (Altınordu, Çaybaşı, Fatsa, Gülyalı, İkizce, Kabadüz, Perşembe, Ulubey, Ünye) yetiştirilen Hayward kivi çeşidinin kimyasal ve fiziksel özelliklerini tespit etmek amacıyla yürütülmüştür. Çalışma sonucunda yeme olumunda fiziksel özelliklerden meyve ağırlığı 77,540 g ile 114,893 g, meyve eni 47,217 mm ile 53,357 mm, meyve boyu 59,970 mm ile 69,497 mm, meyve kalınlığı 43,467 mm ile 48,377 mm, hacim 77,500 ml ile 110,417 ml, yoğunluk 0,990 g/ml ile 1,063 $\mathrm{g} / \mathrm{ml}$, kabuk kalınlığı 0,777 mm ile $1.333 \mathrm{~mm}$, meyve eti sertliği $0,987 \mathrm{~kg} / \mathrm{cm}^{2}$ ile $1,500 \mathrm{~kg} / \mathrm{cm}^{2}$, meyve suyu randımanı $\% 63,570$ ile \% 69,283 arasında değişim göstermiştir. Kimyasal özelliklerden SÇKM \% 10,433 ile \% 12,150, pH değeri 3,317 ile 3,460, TEA değeri \% 1,170 ile \% 1,387, C vitamini değeri 29,000 mg/100g ile 56,833 mg/100g, toplam kuru madde miktarı \% 14,157 ile \% 15,767, glukoz miktarı 36,140 g/l ile 47,177 g/l, fruktoz miktarı 37,443 g/l ile 49,647 g/l, sukroz miktarı 10,547 g/l ile 18,150 g/l, toplam fenolik madde miktarı 35,922 mg GAE/100g ile 52,900 mg GAE/100g, kül miktarı \% 7,030 ile \% 11,277, fosfor miktarı 49,333 mg/kg ile 119,333 mg/kg, potasyum miktar1 2166,330 mg/kg ile 2264,330 mg/kg, sodyum miktarı 13,167 mg/kg ile 20,233 mg/kg, kalsiyum miktarı 64,333 mg/kg ile 250,333 mg/kg, magnezyum miktarı 13,333 mg/kg ile 103,333 mg/kg aralı̆̆ında değişim göstermiştir. Gülyalı ilçesinde yetiştirilen meyvelerin diğer ilçelere oranla kalite bakımından daha iyi özelliklere sahip olduğu tespit edilmiştir.

Anahtar Kelimeler: Kivi, Hayward, Kimyasal, Fiziksel, Ordu

\section{The Important Chemical and Physical Properties of Kiwifruit 'Hayward’ Variety Grown in Ordu Province of Turkey}

\begin{abstract}
This research has been carried out with the aim of determining the chemical and physical properties of 'Hayward' kiwifruit grown in the districts of Ordu province (Turkey) in 2015. As a result of the study, from the physical properties at the eating-ripe; fruit weight, width, length, thickness, volume, density, thickness of fruit rind, texture of pulp, fruit juice yield ranged between $77.540 \mathrm{~g}$ and $114.893 \mathrm{~g}, 47.217 \mathrm{~mm}$ and $53.357 \mathrm{~mm}, 59.970 \mathrm{~mm}$ and $69.497 \mathrm{~mm}, 43.467 \mathrm{~mm}$ and $48.377 \mathrm{~mm}, 77.500 \mathrm{ml}$ and $110.417 \mathrm{ml}, 0.990$ $\mathrm{g} / \mathrm{ml}$ and $1.063 \mathrm{~g} / \mathrm{ml}, 0.777 \mathrm{~mm}$ and $1.333 \mathrm{~mm}, 0.987 \mathrm{~kg} / \mathrm{cm}^{2}$ and $1.500 \mathrm{~kg} / \mathrm{cm}^{2}, 63.570 \%$ and $69.283 \%$, respectively. The chemical properties; total soluble solids ranged between $10.433 \%$ and $12.150 \%$, pH 3.317 and 3.460 , TA $1.170 \%$ and $1.387 \%$, vitamin C $29.000 \mathrm{mg} / 100 \mathrm{~g}$ and $56.833 \mathrm{mg} / 100 \mathrm{~g}$, total dry matter $14.157 \%$ and $15.767 \%$, glucose concentration $36.140 \mathrm{~g} / \mathrm{l}$ and $47.177 \mathrm{~g} / \mathrm{l}$, fructose concentration $37.443 \mathrm{~g} / \mathrm{l}$ and $49.647 \mathrm{~g} / \mathrm{l}$, sucrose concentration $10.547 \mathrm{~g} / \mathrm{l}$ and $18.150 \mathrm{~g} / \mathrm{l}$, total phenolic content 35,922 mg GAE/100g and 52,600 mg GAE/100g, ash 7.030\% and 11.277\%, phosphor content $49.333 \mathrm{mg} / \mathrm{kg}$ and $119.333 \mathrm{mg} / \mathrm{kg}$, potassium content $2166.330 \mathrm{mg} / \mathrm{kg}$ and $2264.330 \mathrm{mg} / \mathrm{kg}$, sodium content $13.167 \mathrm{mg} / \mathrm{kg}$ and $20.233 \mathrm{mg} / \mathrm{kg}$, calcium content $64.333 \mathrm{mg} / \mathrm{kg}$ and $250.333 \mathrm{mg} / \mathrm{kg}$, magnesium content $13.333 \mathrm{mg} / \mathrm{kg}$ and $103.333 \mathrm{mg} / \mathrm{kg}$. It has been identified that the fruits grown in Gülyalı district have way better properties in terms of quality compared with other districts.
\end{abstract}

Keywords: Kiwifruit, Hayward, Chemical, Physical, Ordu

*e-mail: szbostan@hotmail.com

Ordu Üniversitesi Fen Bilimleri Enstitüsünce kabul edilen Yüksek Lisans Tezinden hazırlanmıştır Bu çalışma Ordu Üniversitesi Bilimsel Araştırma Projeleri Birimince desteklenmiştir (Proje No: TF-1410) 


\section{Giriş}

Kivi (Actinidia deliciosa) sarılıcı, tırmanıcı, yaprağını döken, çok yıllık bir ılıman iklim meyve türüdür. Kültüre alınması en çok 50-60 yıl, Akdeniz ülkelerinde yetiştiriciliği ise 15-20 yıl öncesine dayanan bu tür çok hızlı bir gelişme göstermiştir. Son yıllara kadar bazı ülkelerde üretim alanı her 2 yılda bir ikiye katlanmıştır. Yüksek besin değeri, bileşiminde bulunan vitamin ve mineraller, görünüşü, kolay muhafaza edilebilmesi, değerlendirme çeşitliliği ve oldukça geniş adaptasyon özelliği üretim ve tüketim artışlarında önemli rol oynamaktadır [1].

Anavatanı Çin olan kivinin ilk örnekleri 1900'lü yılların başlarında Yeni Zelanda'ya götürülmüştür. 1970'li y1llardan sonra İtalya, Şili, Fransa, Yunanistan ve Japonya gibi ülkelerde de yetiştirilmeye başlanmış ve hızla yayılmıştır. Actinidia'ların meyve bileşiminde en önemli ve dikkat çekici unsur C vitamini içeriğidir. Meyve etinin 100 gramında 100-400 mg C vitamini olduğu belirlenmiştir. Ayrıca 100 gram meyve etinde; toplam kuru madde miktarının 15-22 g, organik asitlerin 1,0-1,6 g, toplam şekerlerin 7,5-13,0 g, proteinlerin 0,5-1,5 g, yağların 0,3-0,9 g, pektinin 0,3-0,9 g, ham lifin 1,1-2,9 g, minerallerin (kül) 0,7-1,0 g olduğu saptanmıştır. Hayward kivi çeşidi bütün üretici ülkelerde en çok ve en yaygın yetiştirilen çeşit olup meyveleri iri (90-100 g), oval (68x55 mm boyutlarında); kabuk yeşilimsi-kahverengi ve sık, ince ve yumuşak tüylüdür. Meyve sap1 $6 \mathrm{~cm}$ uzunluğundadır. Meyve eti parlak yeşil, orta şekerli ve bol suludur. En uzun süre depolanabilen kivi çeşididir [1].

FAO verilerine göre 2014 yllında dünyada 3.447 .605 ton kivi üretilmiş olup Çin 1.840 .000 ton üretimi ile ilk sırada yer almış, bunu 506.958 ton ile İtalya, 410.746 ton ile Yeni Zelanda, 266.017 ton ile Şili, 171.510 ton ile Yunanitan, 62.000 ton ile Fransa, 43.165 ton ile İran iran takip etmiş olup Türkiye ise 31.795 ton üretimi ve yaklaşı \% 1 'lik oranı ile 8 . sırada yer almıştır [2].

Türkiye'de kivi üretim çalışmalarına 1988 yılında ilk olarak Yalova’da bulunan Atatürk Bahçe Kültürleri Merkez Araştırma Enstitüsü’nde başlanmıştır. Sahil bölgeleri ağılıklı olmak üzere adaptasyon ve demonstrasyon bahçeleri kurulmuştur. Bu çalışmalar sonucunda Karadeniz, Marmara ve Ege sahil bölgelerinin kivi yetiştiriciliğine uygun olduğu saptanmıştır. Bu bölgeler arasında Orta ve Doğu Karadeniz Bölgesi'nin bitkinin ekolojik istekleri bakımından diğer bölgelerden daha uygun olduğu ve kivi yetiştiriciliğinin daha ekonomik olarak yapılabileceği görülmüştür [3].

Doğu Karadeniz Bölgesi’nde tarımla uğraşan insanların tamamına yakınının ana geçim kaynağı çay ve fındıktır. Yörenin ikinci tarım ürünü haline gelmeye başlayan ve her yıl yöre ekonomisine katkısını artırarak sürdüren kivi, üreticiye ek gelir imkânı sağlamaktadır.

Türkiye'de 2016 yılında toplam 25 ilde 43950 ton kivi üretilmiş olup kivi üretimi yapılan alanların yaklaşık \% 55'i Karadeniz Bölgesi'nde bulunmaktadır. Marmara Bölgesi kivi üretimi yapılan alanların yaklaşı \% 40'ına, Akdeniz ve Ege Bölgesi ise yaklaşık \% 5'ine sahiptirler (Tablo 1) [4].

2016 yılı verilerine göre Türkiye kivi üretiminin \% 11'ini karşılamış olan Ordu ilinde 2.974 dekar alanda 4.841 ton kivi üretimi gerçekleştirilmiştir. Bu verilere göre Ordu, Yalova ve Rize'den sonra en çok kivi üretilen il konumunda olmuştur (Tablo 1) [4]. İlde kivi üretiminde öne çıkan ilçeler ise Altınordu, Gülyalı, Perşembe, Fatsa, Ünye, İkizce, Ulubey, Çaybaşı ve Kabadüz'dür (Tablo 2) [4]. 
Kubal C., Mazı B.G., Bostan S.Z.

Tablo 1. Türkiye'deki kivi üretimine ait 2016 y1lı verileri

\begin{tabular}{|c|c|c|c|c|c|}
\hline İl & $\begin{array}{l}\text { Toplu meyveliklerin } \\
\text { alanı (dekar) }\end{array}$ & $\begin{array}{l}\text { Üretim } \\
\text { (ton) }\end{array}$ & $\begin{array}{c}\text { Meyve veren } \\
\text { yaşta omca } \\
\text { sayısı }\end{array}$ & $\begin{array}{c}\text { Meyve vermeyen } \\
\text { yaşta omca } \\
\text { sayısı }\end{array}$ & $\begin{array}{c}\text { Toplam } \\
\text { omca } \\
\text { sayısı }\end{array}$ \\
\hline Yalova & 5.402 & 21.535 & 414.525 & 15.000 & 429.525 \\
\hline Rize & 3.624 & 5.554 & 164.839 & 16.120 & 180.959 \\
\hline Ordu & 2.974 & 4.841 & 150.293 & 17.038 & 167.331 \\
\hline Samsun & 1.848 & 2.337 & 71.171 & 33.949 & 105.120 \\
\hline Trabzon & 1.430 & 2.035 & 60.014 & 23.110 & 83.124 \\
\hline Bursa & 1.961 & 1.829 & 89.381 & 36.025 & 125.406 \\
\hline Giresun & 2.125 & 1.525 & 71.381 & 22.658 & 94.039 \\
\hline Kocaeli & 490 & 1.418 & 24.128 & 10.313 & 34.441 \\
\hline Sakarya & 1.977 & 605 & 159.010 & 2.400 & 161.410 \\
\hline Mersin & 670 & 521 & 22.827 & 7.642 & 30.469 \\
\hline Antalya & 209 & 361 & 9.350 & 2.060 & 11.410 \\
\hline Kastamonu & 214 & 343 & 9.795 & 4.209 & 14.004 \\
\hline Artvin & 564 & 327 & 17.229 & 34.890 & 52.119 \\
\hline Çanakkale & 76 & 182 & 3.835 & 560 & 4.395 \\
\hline Zonguldak & 735 & 145 & 7.795 & 11.068 & 18.863 \\
\hline İstanbul & 44 & 76 & 1.885 & 275 & 2.160 \\
\hline Muğla & 44 & 70 & 2.475 & 235 & 2.710 \\
\hline Balıkesir & 104 & 65 & 1.950 & 3.250 & 5.200 \\
\hline Düzce & 40 & 63 & 1.895 & 630 & 2.525 \\
\hline Bartın & 249 & 62 & 4.045 & 4.038 & 8.083 \\
\hline Sinop & 60 & 31 & 3.490 & 2.165 & 5.655 \\
\hline Adana & 20 & 19 & 920 & 100 & 1.020 \\
\hline Hatay & 3 & 6 & 200 & 0 & 200 \\
\hline Kırklareli & 0 & & 45 & 40 & 85 \\
\hline Isparta & 7 & & 30 & 188 & 218 \\
\hline
\end{tabular}

Tablo 2. Ordu ilinde kivi üretimine ait 2016 y1lı verileri

\begin{tabular}{lcrcrr}
\hline İlçe Adı & $\begin{array}{c}\text { Toplu } \\
\text { meyveliklerin alanı } \\
\text { (dekar) }\end{array}$ & $\begin{array}{c}\text { Üretim } \\
\text { (ton) }\end{array}$ & $\begin{array}{c}\text { Meyve veren } \\
\text { yaşta omca } \\
\text { sayısı }\end{array}$ & $\begin{array}{c}\text { Meyve vermeyen } \\
\text { yaşta omca } \\
\text { sayısı }\end{array}$ & $\begin{array}{c}\text { Toplam } \\
\text { omca } \\
\text { sayısı }\end{array}$ \\
Altınordu & 967 & 1.946 & 53.000 & 830 & 53.830 \\
Gülyalı & 355 & 936 & 19.225 & 300 & 19.525 \\
Perşembe & 525 & 636 & 20.200 & 11.940 & 32.140 \\
Fatsa & 348 & 622 & 16.700 & 2.000 & 18.700 \\
Ünye & 262 & 375 & 13.500 & 500 & 14.000 \\
İkizce & 165 & 122 & 9.430 & 55 & 9.485 \\
Ulubey & 128 & 97 & 7.250 & 129 & 7.379 \\
Çaybaşı & 66 & 37 & 3.350 & 300 & 3.650 \\
Kabadüz & 82 & 34 & 4.000 & 560 & 4.560 \\
Çamaş & 23 & 11 & 1.101 & 0 & 1.101 \\
Kumru & 22 & 11 & 1.100 & 70 & 1.170 \\
Gölköy & 11 & 4 & 360 & 260 & 620 \\
Gürgentepe & 8 & 4 & 400 & 94 & 494 \\
AkkuŞ & 6 & 3 & 347 & 0 & 347 \\
Çatalpınar & 6 & 3 & 330 & 0 & 330 \\
\hline
\end{tabular}

Bu güne kadar bazı çalışmalar yapılmışsa da, Ordu ilinde yetiştirilen Hayward kivi çeşidinde ilin genelini yansıtacak şekilde ve özellikle kivinin kimyasal bileşenleri konusunda kapsamlı bir çalışma yapılmamıştır. Bu çalışmanın amacı da Ordu ilinde yetiştirilen Hayward kivi çeşidinin kimyasal bileşimi ve fiziksel özelliklerini ayrıntılı olarak belirlemektir.

\section{Materyal ve Metot}

\subsection{Materyal}

\subsubsection{Araştırma Bahçelerine ve Bitkilere Ait Genel Bilgiler ve Toprak Özellikleri}

$\mathrm{Bu}$ çalışma Ordu ilinin kivi üretiminde önemli merkezleri olan ve uzun yıllar ortalamalarına göre en fazla üretim gerçekleştiren Altınordu, Çaybaşı, Fatsa, Gülyalı, İkizce, Kabadüz, Perşembe, Ulubey ve Ünye ilçeleri olmak üzere toplam 9 ilçede yetiştirilen Hayward kivi çeşidinde yürütülmüştür.

Araştırma bahçelerinin büyüklüğü $500 \mathrm{~m}^{2}$ ile $20.000 \mathrm{~m}^{2}$, verim $9 \mathrm{~kg}$ ile $83 \mathrm{~kg}$, rakım $5 \mathrm{~m}$ ile 496 m ve hasat tarihleri 10 ile 15 Kasım arasında değişmiştir (Tablo 3). 
Tablo 3. Araştırma bahçelerine ait genel bilgiler

\begin{tabular}{|c|c|c|c|c|c|c|c|c|c|}
\hline İlçe & $\begin{array}{c}\text { Tesis } \\
\text { Yılı }\end{array}$ & $\begin{array}{c}\text { Bahçe } \\
\text { Büyüklüğü } \\
\left(\mathbf{m}^{2}\right)\end{array}$ & $\begin{array}{c}\text { Dikim } \\
\text { Mesafesi } \\
\text { (m) }\end{array}$ & Sayısı & $\begin{array}{c}\text { Verim } \\
\text { (kg/) }\end{array}$ & Koordinat & $\begin{array}{c}\text { Rakım } \\
\text { (m) }\end{array}$ & Yöney & $\begin{array}{l}\text { Hasat } \\
\text { Tarihi }\end{array}$ \\
\hline Altınordu & 2005 & 1.500 & 4-4 & 75 & 26 & 4055'38.85"K 3759'13.96"D & 164 & Güneydoğu & 14.11.2015 \\
\hline Altınordu & 1996 & 2.000 & $4-4$ & 65 & 53 & 4055'37.69"K 3758'9.29"D & 91 & Güneydoğu & 14.11.2015 \\
\hline Altınordu & 2007 & 500 & $4-4$ & 32 & 78 & $40^{\circ} 55^{\prime} 46.51 " \mathrm{~K} 37^{\circ} 58^{\prime} 41.26 " \mathrm{D}$ & 116 & Güneydoğu & 14.11.2015 \\
\hline Çaybaşı & 1995 & 1.000 & $4-5$ & 55 & 36 & $41^{\circ}$ 1'2.42"K 37º 6'54.29"D & 342 & Batı & 12.11.2015 \\
\hline Çaybaşı & 2006 & 1.000 & $5-5$ & 40 & 30 & $41^{\circ} 0^{\prime} 57.01 " \mathrm{~K} 37^{\circ} 6^{\prime} 5.13^{\prime \prime D}$ & 485 & Batı & 12.11.2015 \\
\hline Çaybaşı & 2003 & 1.000 & $4-5$ & 30 & 83 & $41^{\circ} 1^{\prime} 20.28 " \mathrm{~K} 37^{\circ} 5^{\prime} 45.23 " \mathrm{D}$ & 416 & Batı & 12.11.2015 \\
\hline Fatsa & 2001 & 20.000 & $4-5$ & 1200 & 10 & $41^{\circ} 0^{\prime} 55.08 " \mathrm{~K} 37^{\circ} 31^{\prime} 30.77^{\prime \prime D}$ & 7 & Batı & 11.11.2015 \\
\hline Fatsa & 2007 & 1.200 & $4-5$ & 100 & 70 & $40^{\circ} 59^{\prime} 27.32 " \mathrm{~K} 37^{\circ} 33^{\prime} 58.88^{\prime \prime D}$ & 33 & Batı & 11.11.2015 \\
\hline Fatsa & 2009 & 3.500 & $4-4$ & 220 & 29 & $40^{\circ} 59^{\prime} 48.88^{\prime \prime K ~} 37^{\circ} 33^{\prime} 53.41 " \mathrm{D}$ & 26 & Bat1 & 11.12.2015 \\
\hline Gülyalı & 2008 & 1.5000 & $5-3$ & 850 & 47 & $40^{\circ} 58^{\prime} 45.32 " \mathrm{~K} 38^{\circ} 0^{\prime} 6.01 " \mathrm{D}$ & 5 & Doğu & 14.11.2015 \\
\hline Gülyalı & 2011 & 6.500 & $4-4,5$ & 307 & 65 & $40^{\circ} 58^{\prime 2} 27.08 " \mathrm{~K} 37^{\circ} 59^{\prime} 53.92 " \mathrm{D}$ & 6 & Doğu & 14.11.2015 \\
\hline Gülyalı & 2010 & 000 & $4,5-4,5$ & 245 & 81 & $40^{\circ} 58 ' 25.39 " \mathrm{~K} 37^{\circ} 59^{\prime} 57.20^{\prime \prime D}$ & 7 & Doğu & 14.11.2015 \\
\hline İkizce & 2011 & 1.500 & $4-4$ & 65 & 46 & $41^{\circ} 5^{\prime} 18.47^{\prime \prime K ~} 37^{\circ}$ 6'27.18"D & 116 & Bat1 & 13.11.2015 \\
\hline İkizce & 1998 & 3.000 & $4-3$ & 150 & 50 & $41^{\circ} 3^{\prime} 28.82 " \mathrm{~K} 37^{\circ} 4^{\prime} 42.67^{\prime \prime D}$ & 141 & Batı & 13.11.2015 \\
\hline İkizce & 2008 & 4.000 & $4-5$ & 145 & 44 & $41^{\circ} 3{ }^{\prime} 31.75 " K 3^{\circ} 5^{\prime} 21.91 " \mathrm{D}$ & 133 & Batı & 13.11.2015 \\
\hline Kabadüz & 2000 & 3.500 & $4-4$ & 77 & 45 & $40^{\circ} 52^{\prime 2} 26.17 " \mathrm{~K} 37^{\circ} 53^{\prime} 50.80^{\prime \prime D}$ & 309 & Güneydoğu & 12.11.2015 \\
\hline Kabadüz & 2008 & 1.500 & 4-4 & 28 & 53 & 4051'59.62"K 3753'37.91"D & 491 & Güney & 12.11.2015 \\
\hline Kabadüz & 2007 & 5.500 & $4-4$ & 300 & 16 & $40^{\circ} 52^{\prime} 31.59 " \mathrm{~K} 37^{\circ} 53^{\prime} 40.88^{\prime \prime D}$ & 227 & Güney & 12.11.2015 \\
\hline Perşembe & 2005 & 1.000 & $4-4$ & 25 & 80 & 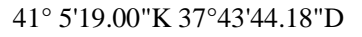 & 364 & Kuzeybat1 & 12.11.2015 \\
\hline Perşembe & 2007 & 1.500 & $4-5$ & 50 & 40 & $41^{\circ} 5^{\prime} 24.31^{\prime \prime K ~} 37^{\circ} 43^{\prime} 44.08^{\prime \prime D}$ & 363 & Kuzeybatı & 12.11.2015 \\
\hline Perşembe & 2000 & 1.500 & $4-4$ & 45 & 33 & $41^{\circ}$ 5'25.40"K 3744'17.71"D & 398 & Kuzeybat1 & 12.11.2015 \\
\hline Ulubey & 2009 & 1.200 & 4-4 & 79 & 50 & $40^{\circ} 50^{\prime} 9.22 " \mathrm{~K} 37^{\circ} 48^{\prime} 58.87^{\prime \prime D}$ & 322 & Güney & 10.11.2015 \\
\hline Ulubey & 2004 & 700 & $4-4$ & 44 & 59 & $40^{\circ} 49^{\prime} 31.26^{\prime \prime K} 37^{\circ} 45^{\prime} 58.07^{\prime \prime D}$ & 320 & Güneybatı & 10.11.2015 \\
\hline Ulubey & 2009 & 1.000 & 4-4 & 55 & 9 & 4049'2.62”K 3747'20.43"D & 496 & Güneybatı & 10.11.2015 \\
\hline Ünye & 2003 & 2.000 & $4-5$ & 99 & 30 & 41 5'3.83"K 37¹1'10.54"D & 242 & Bat1 & 15.11.2015 \\
\hline Ünye & 2007 & 1.000 & $5-5$ & 60 & 50 & $41^{\circ} 5^{\prime} 24.42 " \mathrm{~K} 37^{\circ} 9^{\prime} 13.78 " \mathrm{D}$ & 209 & Batı & 11.11.2015 \\
\hline Ünye & 2004 & 2.200 & $4-5$ & 120 & 50 & $41^{\circ} 6^{\prime} 1.40^{\prime \prime K} 37^{\circ} 23^{\prime} 43.04 " \mathrm{D}$ & 13 & Batı & 11.11 .2015 \\
\hline
\end{tabular}

Araştırmanın yürütüldüğü kivi bahçelerinin değişik yerlerinden 0-25 cm derinlikten alınan toprak örnekleri, Altınordu Ziraat Odası Başkanlığı Toprak Analiz Laboratuvarında analiz edilmiştir.

Araştırma bahçelerinin toprak analiz sonuçları incelendiğinde $\mathrm{pH}$ değerlerinin 5,27-8,05 arasında olması, az kireçli olması, tınlı ve killi-tınlı toprak bünyesine sahip olması nedeniyle bölge topraklarının kivi yetiştiriciliği için uygun olduğu, organik madde bakımından ise yetersiz olduğu saptanmıştır (Tablo 4). Araştırma bahçelerinde yapılan kültürel işlemler genel olarak; budama (kış budaması), gübreleme (hayvan gübresi ve \% 21- \% $26 \mathrm{~N}$ ) ve sulama (damla sulama) işlemlerinin yapıldığı saptanmıştır.

\subsection{2. İklim Özellikleri}

Ordu $40^{\circ}-41^{\circ}$ kuzey paralelleri, $37^{\circ}-38^{\circ}$ doğu meridyenleri arasında yer alan, Karadeniz ikliminin hakim olduğu ildir. Dağlar kıyıya paralel uzandığı için iç kesimlerde farklı, kıyı kesimlerde farklı iklim tipi görülmektedir. Y1llık sıcaklık verileri incelendiğinde, merkezde yıllık sıcaklık ortalaması $14,3^{\circ} \mathrm{C}^{\prime}$ dir.

Uzun yıllar verilerine göre, en sicak ay Ağustos’tur ve ortalama sicaklığı 23,2 ${ }^{\circ} \mathrm{C}$ 'dir, en soğuk aylar ise Ocak ve Şubat ayları olup ortalama sıcaklığı ise $6,8{ }^{\circ} \mathrm{C}$ 'dir. Bu zamana kadar kayda alınan en yüksek sıcaklık 6 Haziran 1994 'te $37,3{ }^{\circ} \mathrm{C}$, en düşük sıcaklık ise 29 Ocak 1964'te $-7,2{ }^{\circ} \mathrm{C}$ olarak ölçülmüştür. Ordu'da yıllık ortalama 1,035 mm yağış görülür. Yağış en az Mayıs, en fazla ise Ekim ve Kasım aylarında görülür. En az yağışın düştüğü aylarda, aylık ortalama yağış miktarı 54 mm'nin altına inmezken, en fazla düştüğü aylarda 135 mm’nin üstüne çıkmaz. Ortalama yağışlı gün sayısı 155'tir [5]. 
Kubal C., Mazı B.G., Bostan S.Z.

Tablo 4. Araștırma bahçelerine ait toprak analiz sonuçları

\begin{tabular}{|c|c|c|c|c|c|c|c|c|c|c|c|c|c|c|}
\hline \multirow[b]{2}{*}{ İlçe } & \multicolumn{2}{|c|}{ Potasyum (kg/da) } & \multicolumn{2}{|c|}{ Fosfor (kg/da) } & \multicolumn{2}{|c|}{ Kireç (\%) } & \multicolumn{2}{|c|}{ Organik Madde (\%) } & \multicolumn{2}{|c|}{ Toplam Tuz (\%) } & \multicolumn{2}{|r|}{ pH } & \multicolumn{2}{|c|}{ Saturasyon (\%) } \\
\hline & Sonuç & Durumu & Sonuç & Durumu & Sonuç & Durumu & Sonuç & Durumu & Sonuç & Durumu & Sonuç & Durumu & Sonuç & Durumu \\
\hline Altınordu & 251,47 & Yüksek & 24,45 & Çok Yüksek & 0,079 & Az Kireçli & 3,07 & İyi & 0,013 & Tuzsuz & 6,36 & Hafif Asit & 56 & Killi Tınlı \\
\hline Altınordu & 75,08 & Yüksek & 34,06 & Çok Yüksek & 0,040 & Az Kireçli & 2,50 & Orta & 0,017 & Tuzsuz & 5,42 & Orta Asit & 48 & Tinli \\
\hline Altınordu & 187,09 & Yüksek & 68,13 & Çok Yüksek & 0,395 & Az Kireçli & 2,80 & Orta & 0,024 & Tuzsuz & 6,71 & Nötr & 50 & Tinlı \\
\hline Çaybaşı & 48,26 & Yüksek & 37,47 & Çok Yüksek & 0,079 & Az Kireçli & 0,87 & Çok Az & 0,024 & Tuzsuz & 6,48 & Hafif Asit & 56 & Killi Tınlı \\
\hline Çaybaşı & 75,44 & Yüksek & 4,41 & $\mathrm{Az}$ & 0,040 & Az Kireçli & 2,91 & Orta & 0,034 & Tuzsuz & 7,96 & Hafif Alkali & 48 & tınlı \\
\hline Çaybaşı & 53,14 & Yüksek & 26,45 & Çok Yüksek & 0,395 & Az Kireçli & 1,27 & $\mathrm{Az}$ & 0,022 & Tuzsuz & 6,62 & Nötr & 44 & Tinli \\
\hline Fatsa & 63,96 & Yüksek & 5,01 & $\mathrm{Az}$ & 0,789 & Az Kireçli & 0,88 & Cok Az & 0,017 & Tuzsuz & 8,02 & Hafif Alkali & 34 & Tinlı \\
\hline Fatsa & 198,21 & Yüksek & 79,75 & Çok Yüksek & 0,079 & Az Kireçli & 1,59 & $\mathrm{Az}$ & 0,022 & Tuzsuz & 6,16 & Hafif Asit & 40 & Tinlı \\
\hline Fatsa & 80,56 & Yüksek & 12,22 & Çok Yüksek & 0,395 & Az Kireçli & 1,08 & $\mathrm{Az}$ & 0,028 & Tuzsuz & 7,52 & Hafif Alkali & 46 & Tinlı \\
\hline Gülyalı & 41,52 & Yüksek & 15,83 & Çok Yüksek & 0,040 & Az Kireçli & 1,47 & $\mathrm{Az}$ & 0,006 & Tuzsuz & 5,62 & Hafif Asit & 36 & Tinli \\
\hline Gülyalı & 53,42 & Yüksek & 14,43 & Çok Yüksek & 0,395 & Az Kireçli & 1,11 & $\mathrm{Az}$ & 0,016 & Tuzsuz & 6,9 & Nötr & 46 & Tinli \\
\hline Gülyalı & 61,46 & Yüksek & 30,66 & Çok Yüksek & 0,395 & Az Kireçli & 0,27 & Çok Az & 0,014 & Tuzsuz & 6,66 & Nötr & 32 & Tunlı \\
\hline İkizce & 73,39 & Yüksek & 67,93 & Çok Yüksek & 0,079 & Az Kireçli & 1,77 & $\mathrm{Az}$ & 0,008 & Tuzsuz & 6,3 & Hafif Asit & 38 & Tinl1 \\
\hline İkizce & 146,54 & Yüksek & 9,82 & Orta & 0,395 & Az Kireçli & 0,91 & Çok Az & 0,031 & Tuzsuz & 8,05 & Hafif Alkali & 44 & Tinli \\
\hline İkizce & 33,65 & Yeterli & 54,70 & Çok Yüksek & 0,079 & Az Kireçli & 1,37 & $\mathrm{Az}$ & 0,017 & Tuzsuz & 6,34 & Hafif Asit & 40 & Tinlı \\
\hline Kabadüz & 70,86 & Yüksek & 30,86 & Çok Yüksek & 0,040 & Az Kireçli & 2,05 & Orta & 0,004 & Tuzsuz & 5,51 & Hafif Asit & 42 & Tinlı \\
\hline Kabadüz & 165,10 & Yüksek & 18,84 & Çok Yüksek & 0,079 & Az Kireçli & 1,58 & $\mathrm{Az}$ & 0,016 & Tuzsuz & 6,34 & Hafif Asit & 40 & Tinl1 \\
\hline Kabadüz & 223,06 & Yüksek & 45,28 & Çok Yüksek & 0,079 & Az Kireçli & 1,61 & $\mathrm{Az}$ & 0,025 & Tuzsuz & 6,08 & Hafif Asit & 48 & Tinlı \\
\hline Perşembe & 132,08 & Yüksek & 29,05 & Çok Yüksek & 0,040 & Az Kireçli & 1,59 & $\mathrm{Az}$ & 0,006 & Tuzsuz & 5,54 & Hafif Asit & 50 & Tinlı \\
\hline Perşembe & 125,33 & Yüksek & 14,23 & Çok Yüksek & 0,040 & Az Kireçli & 1,57 & $\mathrm{Az}$ & 0,010 & Tuzsuz & 5,27 & Orta Asit & 48 & Tinlı \\
\hline Perşembe & 124,73 & Yüksek & 107,80 & Çok Yüksek & 0,040 & Az Kireçli & 2,68 & Orta & 0,018 & Tuzsuz & 5,45 & Orta Asit & 62 & Killi Tınlı \\
\hline Ulubey & 182,60 & Yüksek & 50,49 & Çok Yüksek & 0,395 & Az Kireçli & 1,27 & $\mathrm{Az}$ & 0,023 & Tuzsuz & 7,15 & Nötr & 46 & Tinl1 \\
\hline Ulubey & 192,21 & Yüksek & 32,26 & Çok Yüksek & 0,040 & Az Kireçi & 1,69 & $\mathrm{Az}$ & 0,008 & Tuzsuz & 5,93 & Hafif Asit & 32 & Tinlı \\
\hline Ulubey & 72,91 & Yüksek & 19,84 & Çok Yüksek & 0,118 & Az Kireçli & 1,03 & $\mathrm{Az}$ & 0,019 & Tuzsuz & 6,56 & Nötr & 52 & Killi Tınlı \\
\hline Ünye & 70,08 & Yüksek & 36,87 & Çok Yüksek & 0,079 & Az Kireçli & 1,14 & $\mathrm{Az}$ & 0,023 & Tuzsuz & 6,52 & Nötr & 54 & Killi Tınlı \\
\hline Ünye & 102,22 & Yüksek & 34,26 & Çok Yüksek & 0,395 & Az Kireçli & 1,39 & $\mathrm{Az}$ & 0,035 & Tuzsuz & 7,95 & Hafif Alkali & 46 & Tinli \\
\hline Ünye & 21,03 & Orta & 7,21 & Orta & 0,079 & Az Kireçli & 1,39 & $\mathrm{Az}$ & 0,005 & Tuzsuz & 6,17 & Hafif Asit & 50 & Tinl1 \\
\hline
\end{tabular}

Tablo 5. Ordu İli 2015 yll iklim verileri

\begin{tabular}{|c|c|c|c|c|c|c|c|c|c|c|c|c|c|}
\hline İklim Elemanları & Ocak & Şubat & Mart & Nisan & Mayıs & Haziran & Temmuz & Ağustos & Eylül & Ekim & Kasım & Aralık & Ort. \\
\hline Ort. Sicaklık $\left(\mathrm{C}^{\circ}\right)$ & 7,4 & 8,7 & 8,7 & 10,8 & 16,2 & 21,5 & 23,9 & 25,7 & 23,6 & 17,0 & 13,8 & 8,3 & 15,5 \\
\hline Ort. En Yüksek Sicaklık (Cº) & 18,6 & 24,7 & 20,3 & 30,6 & 24,4 & 28,1 & 30,9 & 32,9 & 30,2 & 26,2 & 24,7 & 16,1 & 25,6 \\
\hline Ort. En Düşük Sıcaklık $\left(\mathrm{C}^{\circ}\right)$ & $-3,3$ & 0,3 & 2,7 & 3,7 & 7,7 & 15,2 & 17,7 & 18,4 & 18,6 & 11,0 & 6,3 & $-0,2$ & 8,1 \\
\hline Ort. Nispi Nem (\%) & 64,3 & 66,3 & 76,4 & 68,0 & 75,6 & 73,7 & 68,4 & 69,3 & 72,0 & 78,0 & 59,7 & 66,6 & 69,9 \\
\hline Aylık Toplam Yağış Ort. (mm ) & 111,6 & 60,3 & 102,4 & 99,9 & 52,7 & 68,8 & 18,6 & 51,2 & 20,7 & 241,7 & 74,3 & 156,7 & 88,2 \\
\hline Ort. Rüzgâr Hızı $(\mathrm{m} / \mathrm{sn})$ & 1,3 & 1,2 & 1,2 & 14 & 1.1 & 1,3 & 1,3 & 14 & 1.2 & 1,2 & 1,3 & 1,3 & 1,3 \\
\hline
\end{tabular}


Kivi bitkisi kışları 1lık, yazları ise sıcak ve nemli bir iklime gereksinim duymaktadır. Don olayları kivi yetiştiriciliğini kısıtlayan en önemli faktörlerden birisidir. Bu sebeple gözlerin sürmesi ile hasat ve yaprak dökümü arasında 230-260 gün don olmayan gelişme süresi gereklidir. Büyüme ve gelişme döneminde $20-25^{\circ} \mathrm{C}$ sıcaklığa ve 16 saat ışıklanmaya ihtiyaç duyarlar. Vejetasyon döneminde ise düzenli olarak ortalama 800-1.400 mm yağış alan bölgelerde rahatlıkla yetiştirilebilmektedir. Bu kriterler göz önüne alındığında Ordu İli kivi yetiştiriciliğ̣i için uygundur [6].

Ordu Meteoroloji İstasyon Müdürlüğü’nden alınan verilere göre, çalışma y1lı olan 2015 yılında en sıcak ayların Temmuz- Ağustos ayları olduğu en soğuk ayın Ocak Ayı olduğu, bu ayda en düşük sıcaklığın sıfırın altında $(-3,3)^{\circ} \mathrm{C}^{\prime}$ ye kadar indiği belirlenmiştir (Tablo 5).

\subsection{Yöntem}

Çalışmada 9 ilçeden 3'er bahçe seçilmiştir. Bahçelerin seçiminde bakım koşullarının aynı olmasına ve yerlerinin farklı olmasına dikkat edilmiştir. Seçilen bahçelerden, bahçeyi temsil edecek şekilde 10'ar kg ürün hasat edilmiştir. Hasat zamanı meyvelerde SÇKM değerinin yaklaşı \% 6,5-7,0 olduğu zaman belirlenmiştir. Örnekler, yeme olumuna getirmek amacıyla yapılan karpit uygulamasına kadar olan sürede, $+4{ }^{\circ} \mathrm{C}^{\prime}$ lik soğuk hava deposunda bekletilmiştir. Daha sonra meyve örneklerine $\% 0,7$ oranında karpit uygulanıp yeme olumuna gelmesi için 1 hafta bekletilmiştir [7]. Bunun için meyvelerin yerleştirildiği poşete bir kap içerisinde karpit koyulmuş ve karpit sslatıldıktan sonra ağılzları sıkıca kapatılmıştır (Şekil 1). Meyvelerdeki analiz ve ölçümler yeme olumundaki 10 örnek üzerinde yapılmıştır.
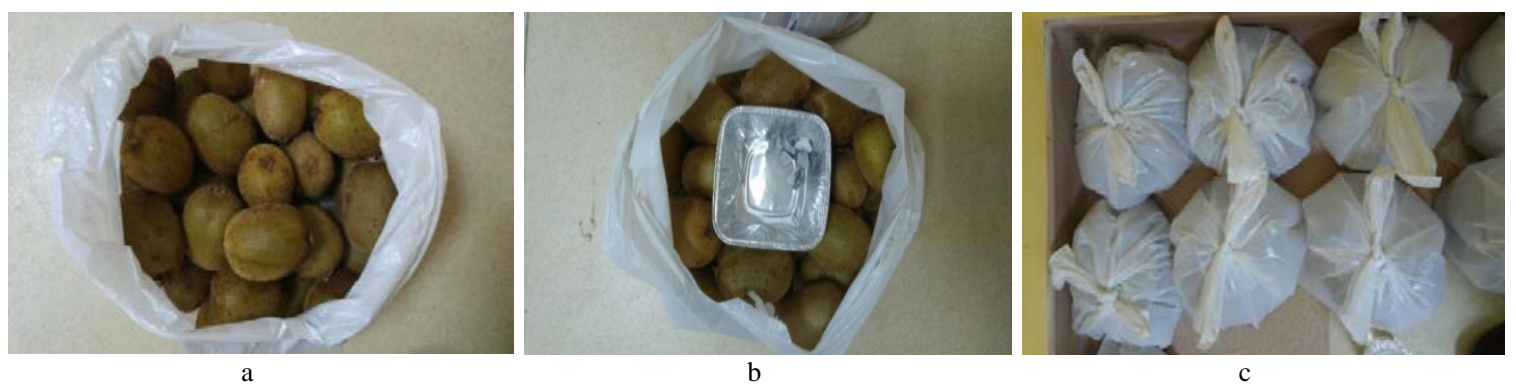

Şekil 1. Kivi meyvelerinin a: poşetle, b: karpit ile muamele, c: paketlenmiş görünümü

\subsubsection{Arazi Çalışmaları}

Arazi çalışmaları sırasında bahçe tesis yılı bahçe sahibinden; her bir bahçenin büyüklüğü ile sıra arası ve üzeri dikim mesafeleri ölçümle; bahçenin koordinatları, rakımı ve yöneyi GPS ile; omcaların verimi her bahçeden elde edilen toplam ürün miktarının bahçe sahibinden öğrenilmesi ve toplam sayısına bölünerek ortalama verimlerin hesaplanmasıyla; hasat tarihleri meyvelerin ağaç olumuna geldiğinin (SÇKM'nin \% 6,5-7,0 olduğunda) analiziyle; toprak analizleri örneklerin bahçeyi temsil edecek şekilde alınarak, Altınordu Ziraat Odası bünyesinde toprak analiz laboratuvarında yaptırılmasıyla belirlenmiştir.

\subsubsection{Laboratuvar Çalışmaları}

\subsubsection{Fiziksel Analizler}

Meyve ağırlığı 0,01 gr hassasiyetindeki terazi ile, meyve boyutları 0,01 mm'lik dijital kumpasla; meyve hacmi ölçü silindirinde taşırma yöntemi ile; meyve yoğunluğu kütle/hacim esasına göre; 
meyvelerin kabuk kalınlıkları meyvenin yanak kısmından keskin bir bıçak yardımıyla alınan kabukta dijital kumpasla; meyve eti sertlikleri meyvelerin her iki yanağından kesilmiş olan kabuksuz kısımlarında 8,0 mm'lik uç kullanılarak penetrometre ile; meyve suyu randımanı meyvelerin tartıldıktan sonra blenderden ve ardından meyve suları tülbentten geçirilip ve tartılı \% oranının hesaplanmasıyla; meyvelerin et ve kabuk renk değerleri meyvelerin her iki yanağında $L^{*}, a^{*}$ ve $b^{*}$ cinsinden Konika Minolta CR-400 Chroma Meter ile ve toplam kuru madde miktarı örneklerden 20 gr alınıp petri kaplarına konularak 0,01 gr duyarlılıktaki terazi ile tartılması, $105{ }^{\circ} \mathrm{C}$ sicaklıkta 17 saat süreyle etüvde bekletilmesinden sonra tekrar tartılması, sabit ağırlık elde edildiğinde son tartılan meyve ağırlı̆̆ ilk tartılan meyve ağırlığına oranlanmasıyla belirlenmiştir.

\subsubsection{Kimyasal Analizler}

Suda çözünür kuru madde (Brix), pH değeri, titrasyon asitliği, askorbik asit ve kül analizleri Ordu Üniversitesi Ziraat Fakültesi Bahçe Bitkileri Bölümü Pomoloji Laboratuvarı'nda, toplam fenolik madde ve toplam P analizleri ise Gıda Bölümü Laboratuvarı'nda yapılmıştır. Şeker dağılım miktarları analizi Ordu Üniversitesi Merkezi Araştırma Laboratuvarı'nda yapılmıştır. Toplam K, Ca, Mg ve Na analizleri ise Ordu Arıcılık Enstitüsü Müdürlüğü’nde yapılmıştır.

Suda çözünebilir kuru madde tayininde Uluslararası Meyve Suyu Üreticileri Federasyonu (IFU) tarafından tanımlanan refraktometrik yöntem uygulanmıştır. Kivinin meyve kabuğunu soyup, dilimledikten sonra blendırda parçalanmış, daha sonra meyve posası tülbentten geçirilerek posasından ayrılmıştır. Elde edilen meyve suyundan refraktometreye birkaç damla damlatılmış ve okuma yapılmıştır.

Kivi örneklerinde şeker (sakkaroz, glikoz ve fruktoz) analizleri HPLC ile Lee ve Coates [8]'in yönteminde ufak değişiklikler yapılarak gerçekleştirilmiş̧ir. Analizler için her bir örnekten $100 \mathrm{~g}$ alınmış ve mekanik bir parçalayıcı ile parçalandıktan sonra $4{ }^{\circ} \mathrm{C}$ 'de $10000 \mathrm{xg}$ de $10 \mathrm{dk}$. santrifüj edilmiş ve üstteki berrak kısım alınıp 0,25 $\mu \mathrm{m}^{\prime}$ 'lik filtrelerden geçirilerek süzülmüştür. Daha sonra elde edilen ekstrakt doğrudan Thermo UltiMate 3000 model ERC RefractoMax 520 refraktif indeks dedektörlü HPLC'ye enjekte edilerek örneklerdeki şeker miktarları belirlenmiştir. Taşıyıcı faz olarak 0,25 $\mu$ m'lik filtrelerden geçirilen ve ulturasonik su banyosunda degaz edilen ultra saf su kullanılmıştır. Analiz HyperREZ XP $\mathrm{Na}+(300$ x 7,7 mm) karbonhidrat kolonunda 45C de 0,3 ml/dk akış hızında gerçekleştirilmiştir. Örneklerdeki şeker konsantrasyonlarının belirlenmesinde dış standart yöntemi kullanılmıştır. $\mathrm{Bu}$ amaçla sakkaroz, glikoz ve fruktoz (Sigma\&Aldrich) standartlarından 5 farklı konsantrasyonda kalibrasyon çözeltileri hazırlanmış, HPLC analizleri yapılmış ve elde edilen verilere doğrusal regresyon analizi uygulanmış, eğriyi tanımlayan eşitlik hesaplanmıştır. Bu eşitlik kullanılarak, kivi örneklerindeki şeker miktarları belirlenmiştir.

pH değeri potansiyometrik olarak pH-metre ile saptanmıştır. Kivi meyvesinden çıarılan meyve suyuna $\mathrm{pH}$-metre daldırılmış ve değer sabitleninceye kadar beklenmiş, değer sabitlenince okuma yapılmıştır.

Titrasyon asitligi $\mathrm{pH}$ ile izlenerek yürütülen titrasyonla belirlenmiştir. Bu amaçla $20 \mathrm{~g}$ pulp üzerine $20 \mathrm{ml}$ saf su konularak elde edilen karışım kaba filtre kağıdından süzülerek ve filtrattan $10 \mathrm{ml}$ alınarak pH'sı 8,2 oluncaya kadar 0,1 N NaOH ile titre edilmiştir. Harcanan baz çözeltisi miktarından titrasyon asitligi (susuz sitrik asit olarak) hesaplanmıştır. 


$$
A=\frac{\mathrm{S} \times \mathrm{N} \times \mathrm{F} \times \mathrm{E}}{\mathrm{C}} \times \quad \begin{aligned}
& 10 \\
& 0
\end{aligned}
$$

$\mathrm{A}=$ Sitrik asit miktarı, $\mathrm{g} / 100 \mathrm{ml}$ meyve suyu

$\mathrm{S}=$ Kullanılan sodyum hidroksidin miktarı, $\mathrm{ml}$

$\mathrm{N}=$ Kullanılan sodyum hidroksidin normalitesi

$\mathrm{F}=$ Kullanılan sodyum hidroksidin faktörü

$\mathrm{C}=$ Alınan örnek miktarı, $\mathrm{ml}$

$\mathrm{E}=$ İlgili asitin equivalent değeri (sitrik asit $=0,064 \mathrm{~g})$

Askorbik asit miktarı kitler kullanılarak Reflectoquant sisteminde belirlenmiştir. 14 gr okzalik asitle, 1 litre saf su karıştırılırak çözelti elde edilmiştir. Çözeltiden $50 \mathrm{ml}$, soyulmuş meyveden 5 gr tartılmış ve blendırda homojenize olana kadar karıştırılmıştır. Daha sonra bu karışıma askorbik asit kiti daldırılmış ve cihazda okuma yapılmıştır [9].

Toplam fenolik madde miktarının belirlenmesinde Folin-Ciocalteu yöntemi [10 ve 11] kullanılmıştır. Bunun için 5 gram örnek tartılarak üzerine \% 80'lik metanol çözeltisinden $50 \mathrm{~mL}$ ilave edilmiş, $30 \pm 2^{\circ} \mathrm{C}$ sıcaklıkta 4 saat boyunca $200 \mathrm{~d} / \mathrm{d}$ hızda çalkalanmıştır. Ekstrakt süzüldükten sonra filtrat $6000 \mathrm{~d} / \mathrm{dk}$ hızda 15 dakika süreyle santrifüj edilmiştir ve berrak kısım toplam fenolik madde miktarının belirlenmesinde kullanılmıştır. $60 \mu \mathrm{L}$ örnek 3,48ml saf su ve $300 \mu \mathrm{L}$ Folin-Ciocalteu çözeltisi ile karıştırıldıktan sonra oda sıcaklığında 5 dakika karanlıkta bekletilmiştir. Daha sonra bu karışıma 900 $\mu \mathrm{L}$ \%20'lik $\mathrm{Na}_{2} \mathrm{CO}_{3}$ çözeltisi konulup $40{ }^{\circ} \mathrm{C}$ deki su banyosunda $30 \mathrm{dk}$. karanlıkta bekletilerek spektrofotometrede 760 nm'de okuma yapılmıştır. Sonuçlar gallik asit standardı kullanarak mg gallik asit/100 g taze ağırlık üzerinden ifade edilmiştir.

Kül ananlizi için önce örneklerin konulacağı krozenin darası kaydedilmiştir. Daha sonra numuneden 3-5 g örnek krozeye tartılarak alınmıştır. Krozeler bir gece $110^{\circ} \mathrm{C}$ 'da etüvde bekletilmiştir. Böylece örneğin yavaş yavaş kuruması sağlanmıştır. Daha sonra $520{ }^{\circ} \mathrm{C}$ 'deki kül fırınına koyularak 7 saat bekletilmiştir, Daha sonra krozeler desikatöre alınarak oda sıcaklığına gelene kadar bekletilmiş ve tartım yapılmıştır.

$$
\begin{aligned}
& \qquad \% \text { Kül }=\left[\left(\mathrm{M}_{2}-\mathrm{M}_{1}\right) / \mathrm{m}\right] \times 100 \\
& \mathrm{M}_{2}=\text { Yakmadan sonraki kroze+ kül ağırlığ1 } \\
& \mathrm{M}_{1}=\text { Sabit tartıma getirilen krozenin ağırlığ } 1 \\
& \mathrm{~m}=\text { Alınan örnek ağırlığ }
\end{aligned}
$$

Örneklerinin fosfor içeriğinin belirlenmesinde Reflectoquant RQfleks plus (Merck, Germany) reflektometre cihazı ve fosfat test kiti kullanılmıştır. Analiz kitle beraber gelen kimyasallar ve protokol kullanılarak gerçekleştirilmiştir [12].

Toplam mineral madde analizleri K, Na, Ca ve Mg Atomik Absorbsiyon Spektrometresi (AAS) cihazı ile NMKL metoduna göre yapılmıştır. Bu metoda göre 5 gr numune porselen krozelere tartılmış ve 1sıtıcı tablada $15 \mathrm{dk} .100{ }^{\circ} \mathrm{C}$ 'yi geçmeyen sıcaklıkta ön yakma işlemi gerçekleştirilmiştir. Ön yakma işleminden sonra numuneler $550{ }^{\circ} \mathrm{C}$ 'e ayarlanmış kül firınına konmuş ve 15 saat boyunca kül rengi elde

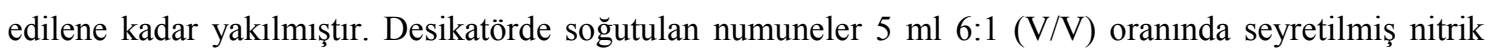


asit ile sulandırılmıştır. Numuneler seyreltik asit uçana kadar 1sıtıcı tabla üzerinde bekletilmiştir. Daha sonra saf su ile 25 ml'ye tamamlanmış ve AAS cihazında okumaya hazır hale getirilmiştir. Her bir elementin numunedeki miktarı AAS standartları ile hazırlanan kalibrasyon eğrilerinden yararlanılarak hesaplanmıştır. Mineral maddelerin ölçümü yapılan dalga boyları sodyum (Na) için 588,995 mm, Potasyum (K) için 766,490 mm, Kalsiyum (Ca) için 317,933 mm ve Magnezyum (Mg) için 279,533mm değerleri kullanılmıştır.

\subsection{Deneme Deseni ve İstatistiksel Analizler}

Çalışma tesadüf blokları deneme desenine göre yürütülmüştür. Her ilçede 3 bahçe (tekerrür) seçilmiştir. İncelenen özelliklerin ilçelere göre değişimini belirlemek amacıyla istatistiki analiz yapılmıştır.

İstatistiksel analizler JMP 11 programında yapılmıştır. Ortalamalar arasındaki farklılıkları karşılaştırmak için LSD testi uygulanmıştır.

\section{Bulgular ve Tartışma}

Ordu ilinde yetiştirilen Hayward kivisinin önemli kimyasal bileşenleri ve fiziksel özellikleri ile bu özelliklerin ilçelere göre değişimi ile ilgili olarak elde edilen istatistik analiz sonuçları aşağıda sunulmuştur.

Meyvedeki kimyasal bileşen değerleri için yapılan varyans analizi sonucunda, sadece askorbik asit $(\mathrm{p}<0,05)$, sukroz $(\mathrm{p}<0,05)$ ve toplam fenolik madde değerleri $(\mathrm{p}<0,01)$ arasındaki farklılıkların ilçelere göre önemli çıktığı (Tablo 6); fiziksel özellikleri için yapılan varyans analizi sonucunda da, meyve yoğunluğu, meyve eti sertliği, kabuk $L^{*}$ değeri, et $L^{*}$ ve $b^{*}$ değerleri dışındaki diğer bütün özelliklere ait değerler arasındaki farklılıkların ilçelere göre önemli çıktığı belirlenmiştir (Tablo 7).

\subsection{Ordu İlinde Yetiştirilen Hayward Kivi Çeşidinin Önemli Kimyasal Bileşenleri}

İncelemeye alınan meyvelerde yeme olumundaki SÇKM değerleri arasındaki farklılıklar ilçelere göre önemsiz çıkmıştır (Tablo 6). Diğer bir çalışmada bu değerin rakıma göre değişebileceği belirtilmiş olup [13] yetiştirilen ekolojiye göre değişmekle birlikte çalışmamızda elde edilen sonuçların literatürdeki [14-15-16-17] sonuçlarla kısmen benzerlik gösterdiği, farklılıkların ekoloji, beslenme koşulları ve olgunlaştırmada kullanılan yöntemlerin farklılıklarından kaynaklanabileceği söylenebilir.

Meyvelerde yapılan analizler sonucunda ortalama $\mathrm{pH}$ değerleri arasındaki farklılıklar ilçelere göre önemsiz çıkmıştır (Tablo 6). Çalışmamızda elde edilen sonuçların genel olarak literatür sonuçları [13-15-17-18-19] aralığında yer aldığını söyleyebiliriz.

Meyvelerin titre edilebilir asit değerleri arasındaki farklılıklar ilçelere göre önemsiz çıkmıştır (Tablo 6). Titre edilebilir asitlik değerleri bakımından sonuçlar, ekolojik farklılıklar dışında, genel olarak literatürle [17-18-20-21] uyum içerisinde gözükmektedir. 
Tablo 6. Ordu ilinde yetiştirilen Hayward kivi çeșidinde kimyasal bileșenlerin ilçelere göre değișimi

\begin{tabular}{|c|c|c|c|c|c|c|c|c|c|c|}
\hline Kimyasal Bileşenler & Altınordu & Çaybaşı & Fatsa & Gülyalı & İkizce & Kabadüz & Perşembe & Ulubey & Ünye & Ortalama \\
\hline SÇKM (\%) & 10,433 & 11,417 & 12,150 & 11,667 & 11,200 & 11,450 & 11,317 & 11,733 & 11,017 & 11,376 \\
\hline $\mathrm{pH}$ & 3,440 & 3,447 & 3,343 & 3,373 & 3,423 & 3,430 & 3,460 & 3,470 & 3,317 & 3,411 \\
\hline Titrasyon asitliği (\%) & 1,263 & 1,200 & 1,387 & 1,267 & 1,170 & 1,217 & 1,247 & 1,170 & 1,267 & 1,243 \\
\hline Askorbik asit (C Vit.) (mg/100g) & $33,667 \mathrm{~b}$ & $29,000 \mathrm{~b}$ & $30,333 \mathrm{~b}$ & $37,833 \mathrm{~b}$ & $30,333 \mathrm{~b}$ & $47,000 \mathrm{ab}$ & $46,500 \mathrm{ab}$ & 56,833 a & $45,833 \mathrm{ab}$ & 39,704 \\
\hline Toplam kuru madde (\%) & 14,493 & 14,330 & 15,187 & 15,767 & 14,263 & 14,157 & 15,233 & 14,503 & 15,487 & 14,824 \\
\hline Glukoz (g/L) & 36,140 & 46,523 & 44,580 & 43,917 & 43,347 & 40,893 & 44,547 & 45,893 & 47,177 & 43,669 \\
\hline Fruktoz $(\mathrm{g} / \mathrm{L})$ & 37,443 & 48,463 & 48,390 & 47,847 & 45,803 & 43,617 & 46,643 & 48,790 & 49,647 & 46,294 \\
\hline Sukroz (g/L) & $1,317 \mathrm{ab}$ & $1,378 \mathrm{ab}$ & 1,552 ab & 1,815 a & $1,496 \mathrm{ab}$ & $1,432 \mathrm{ab}$ & $1,055 \mathrm{~b}$ & $1,374 \mathrm{ab}$ & $1,127 \mathrm{~b}$ & 1,394 \\
\hline Toplam Fenolik (mg GAE/100g) & $35,922 \mathrm{c}$ & $48,184 \mathrm{ab}$ & 40,590 bc & $42,492 \mathrm{bc}$ & 41,006 bc & 50,720 a & 52,600 a & 48,533 a & 51,290 a & 45,704 \\
\hline Kül (\%) & 0,860 & 0,852 & 1,030 & 0,845 & 0,703 & 1,128 & 0,776 & 0,879 & 0,766 & 0,871 \\
\hline Fosfor (mg/kg) & 73,000 & 96,667 & 63,667 & 72,000 & 87,667 & 76,333 & 119,333 & 99,667 & 49,333 & 81,963 \\
\hline Potasyum (mg/kg) & 2224,330 & 2171,000 & 2264,330 & 2187,000 & 2166,330 & 2186,330 & 2237,000 & 2225,000 & 2245,330 & 2211,850 \\
\hline Sodyum (mg/kg) & 19,033 & 19,867 & 13,167 & 19,967 & 20,067 & 19,433 & 20,233 & 19,700 & 19,200 & 18,963 \\
\hline Kalsiyum (mg/kg) & 152,667 & 120,333 & 66,667 & 110,667 & 130,667 & 91,333 & 64,333 & 92,667 & 250,333 & 119,963 \\
\hline Magnezyum (mg/kg) & 48,333 & 80,000 & 13,333 & 66,667 & 103,333 & 21,667 & 21,667 & 13,333 & 46,667 & 46,111 \\
\hline
\end{tabular}

Askorbik asit (LSD: 18,156); Sukroz (LSD: 0,664); Toplam fenolik madde (LSD: 110,672)

Tablo 7. Ordu ilinde yetiştirilen Hayward kivi çeşidinde fiziksel özelliklerin ilçelere göre değişimi

\begin{tabular}{|c|c|c|c|c|c|c|c|c|c|c|}
\hline Fiziksel özellikler & Altınordu & Çaybaşı & Fatsa & Gülyalı & Íkizce & Kabadüz & Perşembe & Ulubey & Ünye & Ortalama \\
\hline Meyve ağırlı̆̆ı (g) & $83,167 \mathrm{~cd}$ & $86,323 \mathrm{bcd}$ & $100,583 \mathrm{ab}$ & 114,893 a & $78,773 \mathrm{~d}$ & $95,753 \mathrm{bc}$ & $95,633 \mathrm{bc}$ & $96,033 \mathrm{bc}$ & $77,540 \mathrm{~d}$ & 92,078 \\
\hline Meyve eni (mm) & $50,403 \mathrm{ab}$ & 49,230 bc & $51,377 \mathrm{ab}$ & 53,357 a & 47,217 c & $51,220 \mathrm{ab}$ & $52,597 \mathrm{a}$ & $52,657 \mathrm{a}$ & 48,580 bc & 50,737 \\
\hline Meyve boyu (mm) & $62,577 \mathrm{~cd}$ & 63,857 bcd & 68,763 a & 69,497 a & 63,177 bcd & $66,420 a b c$ & $63,120 \mathrm{bcd}$ & $67,260 \mathrm{ab}$ & $59,970 \mathrm{~d}$ & 64,960 \\
\hline Meyve kalınlığ 1 (mm) & $45,003 \mathrm{bcd}$ & 45,197 bcd & $46,497 \mathrm{abc}$ & $48,377 \mathrm{a}$ & $43,467 \mathrm{~d}$ & $46,163 \mathrm{abc}$ & $47,200 \mathrm{ab}$ & $47,423 \mathrm{ab}$ & $43,870 \mathrm{~cd}$ & 45,911 \\
\hline Meyve hacmi (ml) & 84,167 bcd & $81,083 \mathrm{~cd}$ & $95,833 \mathrm{~b}$ & 110,417 a & $78,750 \mathrm{~cd}$ & $92,500 \mathrm{bc}$ & 90,417 bcd & $92,083 \mathrm{bc}$ & $77,500 \mathrm{~d}$ & 89,194 \\
\hline Meyve yoğunluğu $(\mathrm{g} / \mathrm{ml})$ & 0,990 & 1,063 & 1,053 & 1,043 & 1,007 & 1,037 & 1,053 & 1,043 & 0,997 & 1,032 \\
\hline Kabuk kalınlığı $(\mathrm{mm})$ & $1,167 \mathrm{ab}$ & 0,800 c & $0,873 \mathrm{bc}$ & 1,333 а & 0,777 c & 0,860 c & $0,927 \mathrm{bc}$ & 1,353 a & $0,977 \mathrm{bc}$ & 1,007 \\
\hline Meyve eti sertliği & 1,273 & 0,987 & 1,290 & 1,163 & 1,027 & 1,500 & 1,097 & 1,140 & 1,167 & 1,183 \\
\hline Kabuk L* değeri & 44,943 & 43,927 & 43,873 & 44,640 & 44,047 & 43,253 & 42,423 & 42,487 & 45,393 & 43,887 \\
\hline Kabuk a* değeri & 3,153 abc & $3,083 \mathrm{abc}$ & $3,480 a b$ & 1,970 c & $3,250 a b$ & $3,320 \mathrm{ab}$ & $2,310 \mathrm{bc}$ & 3,663 а & $2,047 \mathrm{c}$ & 2,920 \\
\hline Kabuk b* değeri & $27,690 \mathrm{ab}$ & $27,573 \mathrm{ab}$ & 26,707 bc & $28,097 \mathrm{ab}$ & $28,390 \mathrm{ab}$ & $25,240 \mathrm{c}$ & 26,653 bc & 25,180 c & 28,950 a & 27,164 \\
\hline Et $L^{*}$ değeri & 56,813 & 51,317 & 54,450 & 54,720 & 52,633 & 51,770 & 52,243 & 52,190 & 53,917 & 53,339 \\
\hline Et a* değeri & $-16,297 \mathrm{c}$ & $-14,547 \mathrm{ab}$ & $-16,007$ c & $-15,857 \mathrm{bc}$ & $-14,127$ a & $-16,360$ c & $-15,693 \mathrm{bc}$ & $-16,930$ c & $-15,560 \mathrm{bc}$ & $-15,709$ \\
\hline Et $b^{*}$ değeri & 32,070 & 28,650 & 31,350 & 32,580 & 28,050 & 31,027 & 31,037 & 31,027 & 30,657 & 30,716 \\
\hline Meyve suyu randımanı (\%) & $63,570 \mathrm{~d}$ & 69,283 a & 66,407 abcd & 69,170 a & $65,683 \mathrm{bcd}$ & $67,070 \mathrm{abc}$ & $68,407 \mathrm{ab}$ & $64,970 \mathrm{~cd}$ & $67,720 \mathrm{abc}$ & 66,920 \\
\hline
\end{tabular}

Meyve ağırlı̆̆ı (LSD: 15,127); Meyve eni (LSD: 2,962); Meyve boyu (LSD: 4,377); Meyve kalınlı̆̆ı (LSD: 2,629); Meyve hacmi (LSD: 14,386) Kabuk kalınlı̆̆ı (LSD: 0,298); Kabuk a değeri (LSD: 1,186); Kabuk b değeri (LSD: 2,220); Et a değeri (LSD: 1,433); Meyve suyu randımanı (LSD: 3,061) 
Meyvelerde yapılan analizler sonucunda Askorbik Asit (C Vitamini) değerinin ortalama olarak $39,704 \mathrm{mg} / 100 \mathrm{~g}$ olduğu tespit edilmiştir. En yüksek askorbik asit miktar1 56,833 mg/100 g olarak Ulubey İlçesi’ndeki meyvelerde, en düşük askorbik asit miktarları da aynı istatistiki grupta yer alan 29,000 mg/100g ile Çaybaşı ve 30,333 mg/100g ile Fatsa ve ikizce ilçelerindeki meyvelerde belirlenmiştir (Tablo 6). Bu değer Antalya koşullarında $101 \mathrm{mg} / 100 \mathrm{ml}$ [21]; Ordu'da rakım ve yöneye göre fark ederek 76,19 $\mathrm{mg} / 100 \mathrm{ml}$ ile $111,97 \mathrm{mg} / 100 \mathrm{ml}$ arasında [13]; Yalova koşullarında $46,4 \mathrm{mg} / 100 \mathrm{ml}$ [22]; Ege Bölgesi’nde 69,3 mg/100 g [18]; Giresun koşullarında 43,056 mg/100 g [17] ve yurt dışında yapılan bir çalışmada $85 \mathrm{mg} / 100 \mathrm{~g}$ [23] olarak belirlenmiştir. Çalışmalarda elde edilen bulgulardan askorbik asit miktarının ekolojiye ve beslenme koşullarına bağlı olarak çok değişkenlik arz ettiği ve birbirine benzer ekolojilerde ve yetişme koşullarında yeme olumundaki değerlerin benzer olduğu görülmektedir.

Farklı ilçelerden alınan meyvelerdeki analizler sonucunda ortalama toplam kuru madde miktarı değerleri arasındaki farklılıklar ilçelere göre önemsiz çıkmıştır (Tablo 6). Literatür bulgularından da anlaşılacağı üzere [13-17-21-24-25-26-27] oldukça farklı faktörlerin etkisi altında değişim gösteren toplam kuru madde içeriği farklı çalışmalarda farklı değerler almıştır.

Meyvelerdeki glukoz ve früktoz değerleri arasındaki farklılıklar ilçelere göre önemsiz çıkmışıır (Tablo 6). Literatürlerde glukoz ve fruktoz miktarı ile ilgili elde edilen bulgular [17-28-29] bizim bulgularımızla genel olarak benzerlik göstermektedir.

Meyvelerdeki ortalama sukroz miktarı 1,394 g/l olarak tespit edilmiştir. En yüksek sukroz miktarı 1,815 g/l olarak Gülyalı İlçesi’ndeki meyvelerde, en düşük değer de 1,055 g/l ile Perşembe İlçesi'ndeki meyvelerde belirlenmiştir (Tablo 6). Diğer çalışmalarda früktozun kivide en fazla, sakkarozun ise en düşük miktarda olduğu [30]; kivide çözünür katı maddenin esas olarak glukoz ve früktozdan oluştuğu ve sakkaroz miktarının oldukça düşük olduğu [31-32]; kivi meyvesinin kimyasal bileşiminde sakkarozun eser miktarda bulunduğu [29]; Giresun koşullarındaki kivilerde 1,912 g/kg olduğu belirlenmiştir [17]. Literatür bildirişlerine de bakıldığında sukroz miktarının kivide daha az bulunduğu ve bu bakımdan sonuçlarımızın literatür sonuçlarıyla benzerlik arz ettiği görülmektedir.

Meyvelerdeki toplam fenolik madde miktarı ortalama olarak 45,704 mg GAE/100g olarak bulunmuştur. En düşük fenolik madde miktarı 35,922 mg GAE/100g olmak üzere Altınordu İlçesi’nde, en yüksek fenolik madde miktarı ise 52,600 mg GAE/100g olarak Perşembe İlçesi'ndeki meyvelerde belirlenmiştir (Tablo 6). Fenolik maddelere ışığın etkisinin araştırıldığı bir çalışmada, en yüksek fenol düzeyinin meyve tutumundan sonraki 3. haftada görüldüğü [33]; hasat zamanı ile depolama arasındaki ilişkinin fenol içeriğine etkisinin önemsiz olduğu ve bu değerin yaklaşık olarak 25 mg GAE/100 mg ile $62 \mathrm{mg} \mathrm{GAE} / 100 \mathrm{mg}$ arasında değiştiği belirlenmiş̧ir [34]. Literatür sonucu ile çalışma sonuçlarımız uyum içerisindedir.

Meyvelerdeki ortalama kül miktarı değerleri arasındaki farklıllklar ilçelere göre önemsiz çıkmıştır (Tablo 6). Çalışmamızdaki alt ve üst değerler literatür sonuçları [35-36-37-38] aralığında bulunmaktadir.

Meyvelerdeki fosfor ve potasyum değerleri arasındaki farklılıklar ilçelere göre önemsiz çıkmıştır (Tablo 6). Önceki çalışma sonuçlarından da anlaşılacağı üzere [35-36-37-38-39-40] büyük oranda beslenme ve ekolojik koşullar ile analiz yöntemlerine bağlı olarak fosfor içeriği değişebilmektedir. 
Analizi yapılan kivi meyvelerinin sodyum, kalsiyum ve magnezyum değerleri arasındaki farklılıklar ilçelere göre önemsiz çıkmıştır (Tablo 6). Farklı çalışma sonuçları birlikte değerlendirildiğinde [29-35-36-37-38-39-41], örneklerimizdeki sodyum miktarının bazı literatürlere göre düşük bazı literatürlere göre yüksek düzeyde bulunduğu ve kalsiyum ile magnezyum değerlerinin literatüre göre daha düşük düzeyde kaldığı ve bu durumun da ekolojik koşullar ile beslenme şartlarından kaynaklanabileceğini söyleyebiliriz.

\subsection{Ordu İlinde Yetiştirilen Hayward Kivi Çeşidinin Fiziksel Özellikleri}

İncelenen örneklerdeki ortalama meyve ağırlı̆̆ ortalama 92,078 g olarak bulunmuştur. Meyve ağırlıkları 77,540-114,893 g aralığında değişmektedir. En hafif meyveler sirasıyla 77,450 g ile Ünye ve 78,773 g ile İkizce, en ağır meyve ise 114,893 g ile Gülyalı İlçesi'ndeki örneklerden elde edilmiştir (Tablo 7). Ferguson'a göre [35] normal bir kivi meyvesinin ağırlığı 40-150 g aralığında değişmektedir. Beever ve Hopkirk [31] bu değerin 80-120 g aralı̆̆ında; Kılıç [18] Ege bölgesi koşullarında bu değerin 79,25 g; diğer bir başka çalışmada $65 \mathrm{~g}$ [42]; Yalova koşullarında 103- $105 \mathrm{~g}$ arasında [22]; Ordu koşullarında 75,21-113,10 g [20]; Antalya koşullarında 78,6 g [21]; Ünye'de en ağır meyvelerin orta kuşakta 89,561 g [43]; yine Ordu koşullarında en ağır meyvelerin (105,920 g) 3-100 m rakımda ve güney yöneyde [13] ve Giresun koşullarında bu değerin 92,987 g olduğu [17] belirlenmiştir. Çalışma sonucumuza bakıldığında literatür sonuçları ile uyum içinde olduğu, ortalama meyve ağırlığı değerlerinin genel olarak diğer çalışmalarda elde edilen bulgular aralığında yer aldığı görülmektedir.

Meyve boyutlarından meyve eni değerlerine bakıldığında ortalama meyve eninin 50,737 olduğu görülmüştür. Meyve eni bakımından öne çıkan değerlerin sırasıyla 53,357 mm ile Gülyalı, 52,657 mm ile Ulubey ve 52,597 mm ile Perşembe İlçeleri’ndeki aynı istatistiki grupta yer alan örneklerde olduğu görülmüştür. En düşük meyve eni değeri ise 47,217 mm ile İkizce ilçesindeki örneklerde tespit edilmiştir Analizi yapılan meyvelerin ortalama meyve boyu 64,960 mm'dir. Meyve boyuna ait yüksek değerler aynı istatistiki grupta yer alan 69,497 mm ile Gülyalı İlçesinde ve 68,763 mm ile Fatsa İlçesi’nde, en düşük değerler ise 59,970 mm ile Ünye İlçesi'ndeki örneklerden elde edilmiştir. Meyve kalınlığı bakımından örnekler incelendiğinde en yüksek değerin 48,377 mm ile Gülyalı, en düşük değerin ise 43,467 ile İkizce İlçeleri'ndeki kivilerde olduğu saptanmıştır. Ortalama meyve kalınlığı ise 45,911 mm’dir (Tablo 7). Meyve boyutları yönünden çalışmamızda belirlenen değerlerin farklı ekolojilerde yapılan çalışmalara ait değerlerle [13-15-17-18-21-35-44-45-46] uyumlu olduğu, çok belirgin farkl1lıkların olmadığı sonucu ortaya çıkmıştır.

Meyvelerin hacim değeri ortalaması 89,194 ml'dir. Hacmi en fazla olan meyve örneğine 110,417 ml ile Gülyalı İlçesi'nde, hacmi en az olan meyve örneğine ise 77,500 ile Ünye İlçesi'nde bulunan kivilerde rastlanmıştır (Tablo 7). Yeni Zelenda'nın 6 farklı bölgesinde yapılan araştırmada ortalama meyve hacminin yıllara ve bölgelere göre $85-130 \mathrm{ml}$ aralı̆̆ında değiştĭgi tespit edilmiş̧tir [47]. Kaynaş ve ark. meyve hacminin hasat zamanlarına göre değiştiğini [22]; Bostan ve Günay Ordu koşullarında rakım artışına bağlı olarak meyve hacminin azaldığını belirtmektedirler [13]. Diğer taraftan bu değer Antalya koşullarında 81,2 $\mathrm{ml}$ [21] ve Giresun koşullarında 95,182 $\mathrm{ml}$ olarak belirlemiştir [17]. Çalışmamızda bulduğumuz meyve hacmi değerleri ile literatür bulguları uyum içerisindedir. 
Meyve yoğunluğu değerleri arasındaki farklılıklar ilçelere göre önemsiz çıkmış olup (Tablo 7) yapılan diğer çalışmalarda bu değerin yaş ve rakıma göre [20] ve rakım ve yöneye göre değişim gösterdiği [13] belirlenmiştir.

Kabuk kalınlığı en fazla olan kivinin 1,353 mm ile Ulubey ilçesinde bulunduğu tespit edilmiştir. Bunu aynı istatistiki grupta yer alan 1,333 mm ile Gülyalı İlçesi’ndeki meyve örneği takip etmiştir. En az kabuk kalınlığı değerleri ise sırasıyla 0,777 mm ile İkizce, 0,800 Çaybaşı ve 0,860 Kabadüz ilçelerindeki meyvelerden elde edilmiştir. Bu değerler aynı istatistiki grupta yer almaktadır. Ortalama kabuk kalınlığı değeri ise 1,007 mm'dir (Tablo 7). Şeker ve ark. Çanakkale'de ekolojik koşullarında kabuk kalınlığının 0,80 mm ile 0,84 mm aralığında değişim gösterdiğini [48]; Yılmaz Giresun koşullarında ise bu değerin 1,272 mm olduğunu belirtmektedir [17]. Meyve kabuğu kalınlığı değerlerimiz literatürle benzerlik arz etmiştir.

Çalışmamızda yeme olumundaki meyve eti sertliği değerleri arasındaki farklılıklar ilçelere göre önemsiz çıkmıştır (Tablo 7). Beever ve Hopkirk gelişmekte olan kivide meyve dokusunun çok sert olduğunu fakat ilerleyen safhalarında sertliğin azaldığını [31]; Samancı iyi olgunlaşmış, kaliteli meyvelerde sertlik değerinin $1 \mathrm{~kg}$ ve altında olması gerektiğini bildirmektedir [1].

Çalışmada meyve kabuğuna ait $\mathrm{L}^{*}$ ve etine ait $\mathrm{L}^{*}$ ile $\mathrm{b}^{*}$ renk değerlerinin ilçelere göre önemsiz; kabuk a* ve b* değerleri ile et $a^{*}$ değerinin önemli olduğu belirlenmiştir (Tablo 7). Beever ve Hopkirk [31] hasada kadar kivinin meyve kabuğunun ne renginde ne de meyve yüzeyinin yapısında çok fazla değişikliklerin olmadığını, meyve içinde birkaç değişikliğin olduğunu, rengin çok az değiştiğini, göbek kısmının beyaz, et kısmının (perikarp) yeşil kaldığını belirtmektedir. Kaynaş ve ark. meyve iç renginde renk parlaklığı yönünden hasat dönemleri bakımından önemli olmayan farklılıklar gözlemlemişlerdir. Ancak bunun yanında hasat edilen meyvelerin $\mathrm{L}^{*}$ değerinde bir azalmanın olduğunu, iç renkteki parlaklığın kaybolmaya başladığını ve rengin daha mat bir görünüm kazandığını bildirmişlerdir [49]. Thomai ve Stakiotakis meyve olgunlaşması ile depolama sonunda Hayward kivi meyvesinin a* renk değerinin yükseldiğini, $b^{*}$ renk değerinin ise düştüğünü bildirmektedirler [50]. Diğer taraftan kabuk renginin budama ve sürgün gelişimine göre (Uslu, 2006) ve rakıma göre değişebileceği [24]; kivi meyvesinde olgunlaşma ilerledikçe et rengindeki parlaklığı ifade eden L* değerinin azalması ile meyvelerin parlaklığını kaybederek matlaştığı ifade edilmektedir [28].

Meyve suyu randımanı \% 63,570-\% 69,283 aralığında değişim gösterirken, ortalama değeri \% 66,920 olarak bulunmuştur. Örneklerdeki meyve suyu randımanının en az olduğu ilçe \% 63,570 ile Altınordu, en fazla olduğu ilçe ise \% 69,283 ile Çaybaşı'dır (Tablo 7). Testolin ve Crivello'nun bildirişine göre Hayward kivi çeşidinde hasatta ortalama meyve suyu miktarının \% 81,8 olması gerekmektedir [41]. Giresun ekolojisinde hasat olumundaki meyvelerin meyve suyu randımanı da \% 67,827 olarak belirlenmiş olup meyve suyu randımanı değerlerinin biraz daha küçük olmasının nedenlerinin meyve suyu miktarının tespitinde kullanılan yöntemlerin farklı oluşu, bunun yanında belli bir bölge içerisinde meyve suyu miktarının birçok faktör etkisi altında yıldan yıla, bahçeden bahçeye, bir yükseltiden, diğer yükseltiye ve bir yöneyden, diğer yöneye kadar önemli farklılıklar arz edebileceği belirtilmektedir [17]. 


\section{Sonuç ve Öneriler}

Ordu ilinde 9 ilçedeki farklı bahçelerden alınan Hayward kivi çeşidinde meyvelerin yeme olumundaki fiziksel ve kimyasal özellikleri incelenmiş ve elde edilen sonuçlar aşağıda sunulmuştur.

Yapılan varyans analizi sonucunda, kimyasal bileşenlerden sadece askorbik asit, sukroz ve toplam fenolik madde değerleri arasındaki farklılıklar ilçelere göre önemli çıkmıştır. Fiziksel özelliklerden ise meyve yoğunluğu, meyve eti sertliği, kabuk L* değeri et L* ve b* değerleri dişındaki diğer bütün özelliklere ait değerler arasındaki farklılıklar ilçelere göre önemli çıkmıştır.

Meyve ağırlığı ve meyve hacmi bakımından ilçeler arasında istatistiki açıdan önemli farklılıklar tespit edilmiştir. Genel anlamıyla sahil kesiminde bulunan ilçelerde meyve ağırlığının daha yüksek olduğu saptanmıştır. Nitekim en yüksek ağırlığa sahip meyveler sahil kesimindeki Gülyalı $(114,893$ g) İlçesi'nde bulunmuştur.

Meyve eni, boyu ve kalınlığında ilçeler arasında önemli düzeyde farklılıklar olduğu, en, boy ve kalınlık değerinin en fazla olduğu ilçenin Gülyalı ilçesi olduğu tespit edilmiştir. Genel anlamıyla Gülyalı ilçesindeki meyvelerin diğer ilçelere oranla kalite bakımından daha iyi özelliklere sahip meyveler olduğu tespit edilmiştir. Gülyalı ilçesinde bulunan meyvelerin bakım koşullarının daha iyi olduğu gübreleme ve diğer kültürel uygulamaların daha iyi yapıldığı gözlemlenmiştir.

SÇKM değerinin hasat olumundan yeme olumuna kadar artış gösterdiği belirlenmiştir. Hasat olum döneminde \% 6,5-7 olan SÇKM değerinin, yeme olum döneminde ilçelere göre \% 10,4-12,2 aralığında değişim gösterdiği tespit edilmiştir.

Sonuç olarak, Ordu ilindeki Hayward kivi çeşidinin meyve özelliklerinin diğer bölgelerde yetiştirilen meyvelerin kalite özellikleriyle benzerlik gösterdiği ve yapılan kültürel uygulamalar ve yetiştirme koşullarının iyileştirilmesiyle daha kaliteli meyvelerin elde edilebileceği belirlenmiştir. .

\section{Kaynaklar}

[1] Samancı, H. “Kivi (Actinidia) yetiştiriciliği” TAV Yayınları No:22, Yalova, 96-112, 1990.

[2] Anonim, FAO., 2013. http: // www. fao.org (Erişim Tarihi:31.05.2017)

[3] Özdemir, O., Özyazıcı, M.A. "Samsun yöresinde kivinin azotlu gübre ihtiyac1." Ondokuzmayıs Üniversitesi Ziraat Fakültesi Dergisi, 21(3), 303-309, 2006.

[4] Anonim, 2017. “Türkiye kivi üretim miktarlar1.” Türkiye istatistik kurumu, www.tuik.gov.tr (Erişim Tarihi: 31.05 .2017 )

[5] Anonim, “Ordu turizm portalı” http://ordufx.mekan360.com/ (Erişim Tarihi:26.06.2016)

[6] Anonim, “Meteoroloji genel müdürlüğü”. www.mgm.gov.tr (Erişim Tarihi:26.06.2016)

[7] Bal, E., Kök, D. "Kivide (Actinidia deliciosa) farklı dozda karpit uygulamalarının bazı meyve kalite kriterlerine etkileri.” Tekirdă̆ Ziraat Fakültesi Dergisi, 213-219, 2006.

[8] Lee, H.S., Coates, G.A.“Quantitative study of free sugars and myo-inositol in citrus juices by HPLC and literature compilation.” Journal of Liquid Chromatography \& Related Technologies, 14, 2123-2141, 2000.

[9] Anonim, "Reflectoquant, ascorbic acid test (7.76044.0003-6001516376).” Merck KGaA, 64271 Darmstadt, Germany, (Erişim Tarihi:26.06.2016) 
[10] Slinkard, K., Singleton, V. L. "Total phenol analysis, automation and comparison with manual methods.” American Journal of Enology and Viticulture, 28, 49-55, 1977.

[11] Saeedeh, A., Asna, U. “Antioxidant properties of various solvent extracts of mulberry (Morus indica L.) leaves.” Food Chemistry, 102, 1233-1240, 2007.

[12] Anonim, "Reflectoquant, phosphate test (7.76038.0003).” Merck KGaA, 64271 Darmstadt, Germany, (Erişim Tarihi:26.06.2016)

[13] Bostan, S.Z., Günay, K. "Hayward (Actinidia deliciosa Planch) kivi çeşidinin meyve kalitesi üzerine rakım ve yöneyin etkisi.” Akademik Ziraat Dergisi, 3(1), 13-22, 2014.

[14] Mitchell, F.G."Kiwifruit maturity. Perishables handling postharvest technology of fresh horticultural crops.” Coopeartive Extension, Universtiy of California, 63(4), 1988.

[15] Kaynaş, K., Dardeniz, A., Kaya, S. "A research on determining the most suitable harvest maturity of the kiwifruit (Actinidia deliciosa cv. Hayward) harvested at different time intervals." Pakistan Journal of Applied Sciences, 2(12), 1074-1077, 2002.

[16] Zenginbal, H., Özcan, M., Haznedar, A. 2003. "Rize ekolojik şartlarında yetiştirilen kivi çeşitlerinde fenolojik gözlem ve pomolojik analizler üzerine bir araştırma.” Derim, 22(1), 1-9, 2003.

[17] Yılmaz, B. "Giresun koşullarında yetiştirilen Hayward kivi çeşidinde meyve gelişim sürecinde önemli kalite özelliklerinin değişimi." Ordu Üniversitesi, Fen Bilimleri Enstitüsü, Bahçe Bitkileri Anabilim Dall, Yüksek Lisans Tezi, Ordu, 2016.

[18] Kılıç, A. "Kivinin Ege Bölgesi koşullarına adaptasyonu ve meyve özellikleri.” Ege Üniversitesi, Fen Bilimleri Enstitüsü, Bahçe Bitkileri Anabilim Dalı, Yüksek Lisans Tezi, İzmir, 1995.

[19] Hosseinzadeh, J., Feyzollahzadeh, M., Afkarı, A.H. "The physical and chemical properties of kiwifruit harvested at four stages.” Bulgarian Journal of Agricultural Science, 19(1), 174-180, 2013.

[20] Cangi, R., Karadeniz, T. “Ordu'da değişik rakımlarda yetiştirilen Hayward (Actinidia deliciosa) kivi çeşidinde verim ve meyve özellikleri üzerine araştırmalar." Karadeniz Bölgesi Tarım Sempozyumu 4-5 Ocak 1999. Bildiriler. Ondokuz Mayıs Üniversitesi Ziraat Fakültesi, Samsun, 425-432, 1999.

[21] Basım, H. "Kivinin Antalya koşullarında mevsimsel gelişimi üzerinde araştırmalar.” Akdeniz Üniversitesi, Fen Bilimleri Enstitüsü, Bahçe Bitkileri Anabilim Dall, Yüksek Lisans Tezi, Antalya, 2001.

[22] Kaynaş, K., Özelkök, S.G., Samancı, H., Yalçın, T. "Yalova koşullarında yetiştirilen kivi (Actinidia chinnensis cv. Hayward) meyvesinde en uygun hasat olumunun saptanması üzerine bir araştırma.” IV. Bağcılık Sempozyumu, Yalova, 293-297, 1998.

[23] Lombardi- Baccia, G., Cappelloni, M., Lintas, C. "Vitamin C content of kiwifruit as affected by maturity stage and length of storage.” Rivista Della Societa Italiana Di Scienze Dell Alimentazime, 15(1), 45-48, 1986.

[24] Uslu, N.A. "Kivide budama ve sürgün gelişiminin meyve kalitesi ve verim üzerine kantitatif ve kalitatif etkileri.” Ondokuz Mayıs Üniversitesi Fen Bilimleri Enstitüsü Bahçe Bitkileri Anabilim Dall, Doktora Tezi, Samsun, 2006.

[25] Kaynaş, K., Özelkök, S.G., Samanc1, H."Kivide (Actinidia deliciosa) meyve gelişimi, olgunlaşma ve depolama koşulları üzerine araştırmalar.” Bilimsel Araştırmalar ve Güncellemeler Yayın No: 136 Atatürk Bahçe Kültürleri Merkez Araştırma Enstitüsü, Yalova, 92, 1999. 
[26] Velemis, D., Vasilakakis, M., Manolakis, E., Sfakiokatis, E. "Effects of dry matter content of the kiwifruit at harvest on storage performance and quality.” Acta Horticulturae, 444, 637-642, 1997.

[27] Minchin, Peh., Snelgar, W.P., Blattmann, P., Hall, A.J. “Competition between fruit and vegetative growth in Hayward kiwifruit.” New Zealand Journal of Crop and Horticultural Science, 38(2), 101-112, 2010.

[28] Öz, A.T. "Farklı zamanlarda hasat edilen kivilerde (Actinidia deliciosa cv. Hayward) normal ve kontrollü atmosfer koşullarında soğuk muhafaza süresinin etilen biyosentezine etkisi." Uludăg Üniversitesi, Fen Bilimleri Enstitüsü, Bahçe Bitkileri Anabilim Dalı, Doktora Tezi, Bursa, 2006.

[29] Türkmen Özen, İ., Ekşi, A. "Kivi meyvesinin kimyasal bileşenleri ve fonksiyonel özellikleri." Ordu Üniversitesi Bilim ve Teknoloji Dergisi, 2(2), 54-67, 2012.

[30] Banos, S.B., Lona, P.G., Ganesh, S. "Chemical composition of cured kiwifruit after a cool,storage period." Third int. symposium on kiwifruit, Acta horticulturae, 444(2), 599-605, 1997.

[31] Beever, D. J., Hopkirk G. "Fruit development and fruit physiology.” (I. J. Warrington \& G. C. Weston, eds.), Kiwifruits: science and management, Auckland: Ray Richards publisher and NZ society for horticultural science, 97-126, 1990.

[32] Lintas, C., Adorisio, S., Cappelloni, M., Monastra, E. “Composition and nutritional evaluation of kiwifruit grown in Italy” Horticultural Science, 19, p:341-344, 1991.

[33] Montanaro, G., Treutter, D., Xiloyannis, C. "Phenolic compounds in young developing kiwifruit in relation to light exposure: Implications for fruit calcium accumulation.” Journal of Plant Interactions, 2(1), 63-69, 2007.

[34] Tavarini, S., Degl Innocenti, E., Remorini, D., Massai, R., Guidi, L. “Antioxidant capacity, ascorbic acid, total phenols and carotenoids changes during harvest and after storage of Hayward kiwifruit.” Food Chemistry, 107, 282-288, 2008.

[35] Ferguson, A.R. Kiwifruit: A botanical review. In: Horticultural Reviews, (Ed. J. Janıck). Avi. Publishing Company, Inc. Westport Connecticut, 6, 1-64, 1984.

[36] Fourie, P.C., Hansmann, C.F. "Fruit composition of four South African-grown kiwifruit cultivars.” New Zealand Journal of Crop and Horticultural Science, 20, 449-452, 1992.

[37] Çelik, A. Ercişli., S. Turgut, N. "Some physical, pomological and nutritional properties of kiwifruit cv. Hayward.” International journal of food sciences and nutrition, 58(6), 411-418, 2007.

[38] Zolfaghari, M., Sahari, M.A., Barzegar, M. Samadloiy, H. "Physicochemical and enzymatic properties of five kiwifruit cultivars during cold storage.” Food Bioprocess Technology, 3, 239246, 2010.

[39] Castaldo D., Lo Voi A., Trifiro A. Gherardi S. "Composition of kiwi (Actinidia chinensis) puree.” Journal of Agricultural and Food Chemistry, 40, 594-598, 1992.

[40] Park, Y.S., Leontowicz, H., Leontowicz, M., Namiesnik, J., Suhaj, M., Cvikrova' M. Martincova' O., Weisz, M., Gorinstein, S. "Comparison of the contents of bioactive compounds and the level of antioxidant activity in different Kiwifruit cultivars.” Journal of Food Composition and Analysis, 24, 963-970, 2011.

[41] Testolin, R., Crivello, V. “İl kiwi Suo Mondo.” Fed. Reg. Colt. Dir. Veneto. İripa, 1987. 
[42] Özkan, Y., Koçyiğit, Ö. "Sağlık meyvesi kivi.” GOP (Gaziosmanpaşa) Üniversitesi Ziraat Fakültesi Yayını, Tokat, 287, 1995.

[43] Esen, Y., "Ünye yöresi kivi yetiştiriciliğinde meyve gelişiminin ve en uygun hasat zamanının belirlenmesi." Ondokuz Mayıs Üniversitesi Fen Bilimleri Enstitüsü Bahçe Bitkileri Anabilim Dalı Yüksek Lisans Tezi, Samsun, 2009.

[44] Cangi, R., Karadeniz, "Ordu ekolojisinde yetiştirilen Hayward kivi çeşidinde (A. deliciosa) bazı fiziksel ve kimyasal özelliklerin değişimi üzerine bir araştırma." Journal of Qafgaz University, Spring, 7, 169-176, 2001.

[45] Aksu, N. "Kivide budama ve sürgün gelişiminin meyve kalitesi ve verim üzerine kantitatif ve kalitatif etkileri" Ondokuz Mayıs Üniversitesi, Fen Bilimleri Enstitüsü, Bahçe Bitkileri Anabilim Dall, Doktora Tezi, Samsun, 2006.

[46] Farzam, E., Shahbazi, H., Imani, A.A., Gheshlaghi, E.A. "Effect of harvest time on some qualitative and quantitative characteristics of Hayward kiwifruit in the West of Gilan, Iran.” The International Journal of Farming and Allied Sciences, Vol., 2(11) 296-301, 2013.

[47] Hall, A.J., McPherson, H.G., Crawford, R.A., Seager, N.G. "Using early season measurements to estimate fruit volume at harvest in kiwifruit." New Zealand Journal Crop Horticulturae Science, 24(4), 379-391, 1996.

[48] Şeker, M., Dardeniz, A., Kaynaş, K., Ulaş, Z. 2003. "Çanakkale yöresinde yetiştirilen Hayward ve Tomuri kivi çeşitlerinin önemli bitkisel özelliklerinin incelenmesi." Ulusal Kivi ve Üzümsü Meyveler Sempozyumu, Ordu, 46-51, 2003.

[49] Kaynaş, K., Özelkök, İ.S., Samancı, H. "Yalova koşullarında yetiştirilen kivi (Actinidia chinensis cv. Hayward) meyvesinde en uygun hasat olumunun saptanması üzerine bir araştırma." IV. Bağcllk Seтроzуumu, Yalova, 293-297, 1992.

[50] Thomai, T., Sfakiotakis, E. "Effect of low-oxygen atmosphere on quality changes, acetaldehyde and ethanol accumulation in early and late harvest of Hayward kiwifruit." Third int. sym. on kiwifruit. Acta Horticulturae, 444(2), 593-595, 1997. 